\title{
Bipolaris sorokiniana on barley seed in Finland
}

\author{
AARNE KURPPA \\ Department of Plant Pathology, University of Helsinki, \\ SF-00710 HELSINKI 71, Finland
}

\begin{abstract}
Bipolaris sorokiniana is reported as a common fungus in commercially grown barley seed in Finland with possible economic importance. In 1974, when 200 samples of barley seed were surveyed the fungus was identified in 60 per cent of samples. The three following years the incidence was 19,29 and $38 \%$. The mean per cent seeds infected was 3.8 , $1.3,1.2$ and 1.9 respectively. The highest recorded individual $\%$ was 92 . The most severely infected cultivar was Paavo each year. In most cases only the seed cover was invaded by the fungus but also infection in the embryo and the cell leyers surrounding it was observed. Such severely infected seeds did not germinate or the seedlings were readily infected after germination. B. sorokiniana was less frequent in the western parts of the country. Field experiments in 1972-1979 confirmed the same varietal susceptibility which was found by the survey of commercial samples of barley seed. High rainfall and relative humidity in July and August were the main factors associated with increased seed infection incidence.
\end{abstract}

\section{Introduction}

Bipolaris sorokiniana (Sacc. ex Sorok.) Shoem. (syn. Helminthosporium sativum Pamm., King \& Bakke), perfect state Cochliobolus sativus (Ito \& Kurib.) Dastur has a cosmopolitan distribution on many grasses and cereals and causes serious disease and economic losses in spring barley and wheat particularly in warm temperate areas (SPRAQUE 1950, ANDERSON \& BANTTARI 1976). In recent years the fungus has become more frequent in North Western Europe (JøRGENSEN 1974, Mắkelä 1975, Whittle 1977). The sus- ceptible crop is readily infected by the fungus which is able to overwinter in the soil even in cool climate and because many wild grasses act as an inoculum reservoir (JøRGENSEN 1974, Whittle 1977). The diseases the fungus causes are a seedling blight, a foot and root rot, foliar disease, headblight and kernel blight (ANDERSON \& BANTTARI 1976). Up to $15 \%$ of yield losses have been recently reported (WhitTle \& RichaRdSON 1978). There is no earlier information as to when the fungus became common in Finland, but in North Western Europe it happened during the 1950s and 1960s (de TEMPE 1964, JøRGEN-

Index words: Bipolaris sorokiniana, Helminsthosporium sativum, Cochliobolus sativus, common root rot; barley, seed infection 


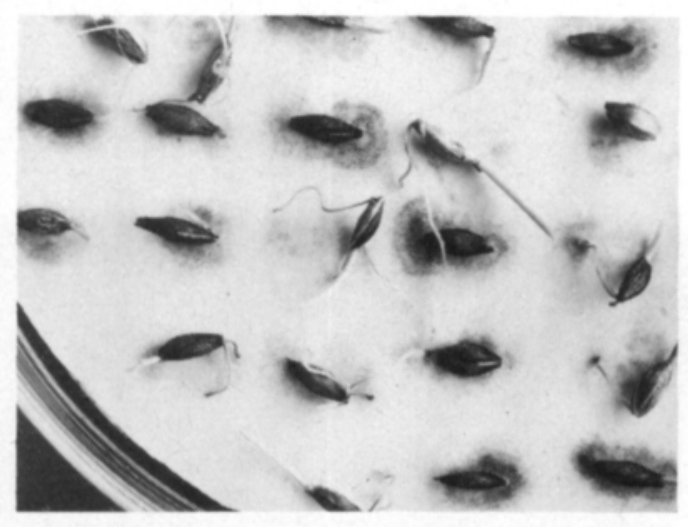

Fig. 1. A barley seed sample cv. Paavo with very high incidence of Bipolaris sorokiniana after 5 days of incubation in a petri dish.

SEN 1969, HeweTt 1975). A later report of KURPPA (1982) assumes the fungus gaining still increasing importance as a pathogen of spring barley in Finland.

\section{Materials and methods}

During the years 1972 to $1979,11-19$ spring barley cultivars grown in field experiments at the University Farm at Viikki were examined each year for the presense of Bipolaris sorokiniana. Experimental seed samples from North Savo Experimental Station, Maaninka were examined during 1972 and 1973. 649 commercial samples of spring barley, including those most commonly sown were taken from those seed lots received annually at the State Seed Testing Institute, Helsinki for testing for purity and germination.

Representative sub-samples of 100 seeds were placed in petri dishes (diameter $14 \mathrm{~cm}$ ), 50 each on wet filter paper and cotton filter. The dishes were incubated at $20-22^{\circ} \mathrm{C}$ for six days and then examined for fungal growth. B. sorokiniana could be readily identified with a stereo microscope at the magnification of 12 to 50 times if it was present in germinating seeds.

The fungi belonging to the other genera were also recorded. The seed lots with high incidence of seed infection were further exa-

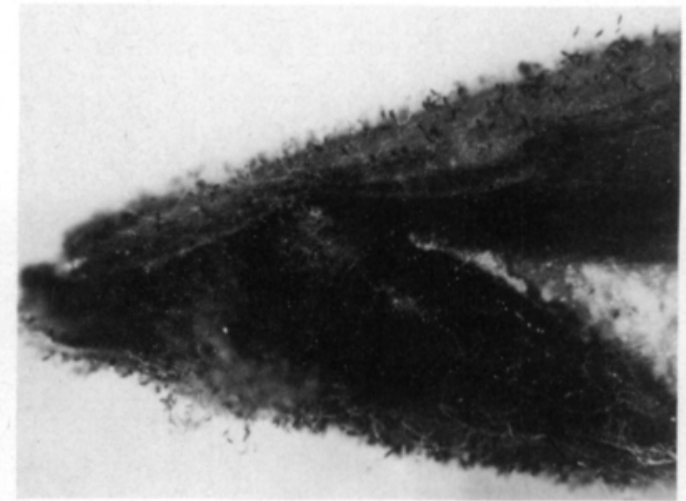

Fig. 2. A seed half with severe embryo infection by the fungus after 4 days of incubation.

mined for possible embryo infection. The seeds were cut into two halves and one half was placed in a petri dish as described above and the other half was discarded. One hundred seeds were examined per a sample. The seed halves were observed after three days of incubation for the localization of the site of infection. During the short incubation time no growth from the seed cover could reach the embryo area, but any fungal growth within the embryo could be easily seen.

Preliminary tests of seed infection incidence included a treatment with $1 \% \mathrm{Na}$ hypochloride solution. Comparison of test results with and without this treatment showed no significant differences and the treatment was discontinued.

The weather conditions during the research period:

The growing seasons 1972-1975 were warmer and seasons 1976-1978 cooler than average. The temperature during the 1979 season was near average. Summers in 1973 and 1975 were very dry and 1976, 1977 and 1979 were abnormally rainy. The precipitation during late summer 1974 was also high (ANON 1972-1979).

\section{Results}

The incidences of Bipolaris sorokiniana in spring barley seed varied marketly during the 


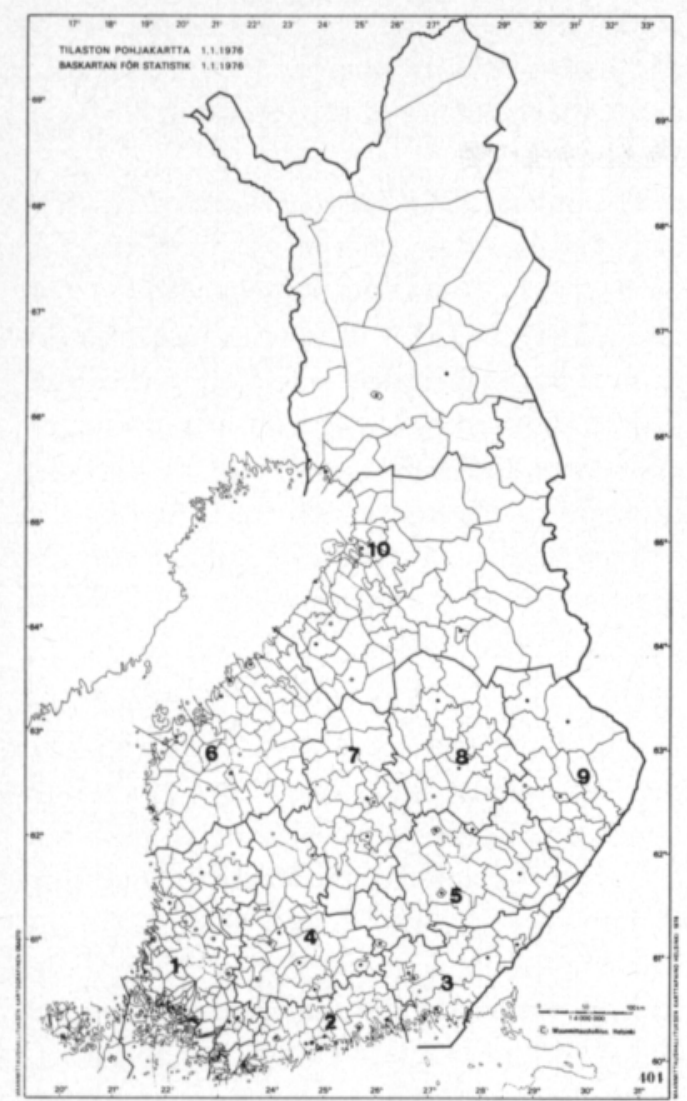

Fig. 3. The regional distribution of the seed samples. See Table 3.

research period 1972-1979. In certain years the fungus was widespread occuring with high levels in susceptible cultivars. Overall figures for seed infection show the fungus was common but associating with certain cultivars. In the seed samples from field experiments at University Farm, Helsinki Viik$\mathrm{ki}$, the fungus was very common in 1972 and 1974 but did not occur at all in 1973 and 1975. From low to moderate incidences were recorded in the following years (Table 1). During dry seasons the infection status of the sowing seed did not have any effect on the infection incidence of new grain yield, but during moist seasons the crop grown from infected seed served as an important source for spore liberation for secondary infection.

Fungal growth in individual seeds was mostly superficial and the fungal hyphae had
(1)

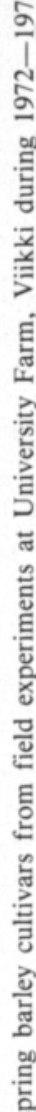


only invaded the seed coat. In 1972 severe infection of embryos or the surrounding layers was detected in many cultivars, particularly cvs Paavo, Mari and Birgitta. The highest individual percentage of embryo infection was recorded with $\mathrm{cv}$. Paavo at $32 \%$. The other common fungus species recorded each year with the survey were Alternaria sp., Cephalosporium sp., Cladosporium sp. and Ulocladium sp.. Also Fusarium species were common after rainy late growing seasons like 1972 and 1974. A survey of spring barley cultivars at North Savo Experimental Station, Maaninka 1972 revealed the following incidence of B. sorokiniana in seed samples $(\%)$ : Balder 10, Etu 13, Karri 9, Lise 0, Mari 10, Paavo 8, Pirkka 0, Pomo 31, Olli 0, Otra 6 and Vigdis 19. Severe infection of the embryo was detected with the cvs Pomo and Vigdis with an incidence of $10 \%$. The following summer the mean percent infected seeds of cv. Vigdis was 60.0.

According to surveys of commercial samples of spring barley in 1974-1977 B. sorokiniana was a common and widespread fungus throughout the country, wherever barley is grown (Table 2). In 1974, when the fungus was exceptionally common, several samples with high incidence of seed infection were recorded. Differences in the incidence were also found between the cultivars. Each year the highest levels occurred in cv. Paavo. All these samples with high $B$. sorokiniana incidence were also severely infected in the embryos.

Clear differences in incidence between geographic areas could not be found, but it seems obvious that fungus is less frequent in Western and South Western parts of the country (Turku and Pori and Vaasa counties) (table 3).

\section{Discussion}

These surveys and other earlier observations of Bipolaris sorokiniana occuring in barley crop by MÄKELÄ (1971, 1972, 1975) and barley seed by KurPPA (1975) show decicively the incidence of the fungus in barley in Finland.

The infection incidence was clearly associated with certain cultivars as also reported by de Tempe (1964), Kietreiber (1973, 1974) and Whittle (1977). The true susceptibility to seed borne infection is related to the invasion to the seed by the fungus as reported by Anderson and BantTARi (1976). Superficial invasion is effectively controlled by the use of mercurial seed treatment but infection in the embryo or the surrounding cell leyers is not controlled.

Differences in the disease incidence and fungal incidence have also been reported between areas and years by JøRGENSEN (1969) and Kietreiber $(1973,1974)$ and these are strongly related to the weather conditions as shown by Couture and Sutton (1977). The higher incidence in central part of the country rather than in the coast area is associated to higher relative humidity and afternoon showers which are more frequent outside the coast area during the critical period of seed ripening.

No regional differences in disease incidence could be found associated to sowing seed because commercially distributed seed is mainly used for sowing. Seed dressing to control the pathogen is increasingly important because it also helps to prevent the accumulation of the fungus as a destructive soil borne pathogen. This is particularly true after rainy growing seasons.

The most important factor in seed infection is the location of the fungus in the seed, either in the seed coat or in the embryo.

Acknowledgements. The State Seed Testing Institute is acknowledged for providing research material. Special thanks are due to professor Eeva Tapio and Dr. Kaiho Mäkelä for the support and good advice they have given me in my work. I also wish to thank Dr. Randall Kelley for linguistic revision of the English text. 


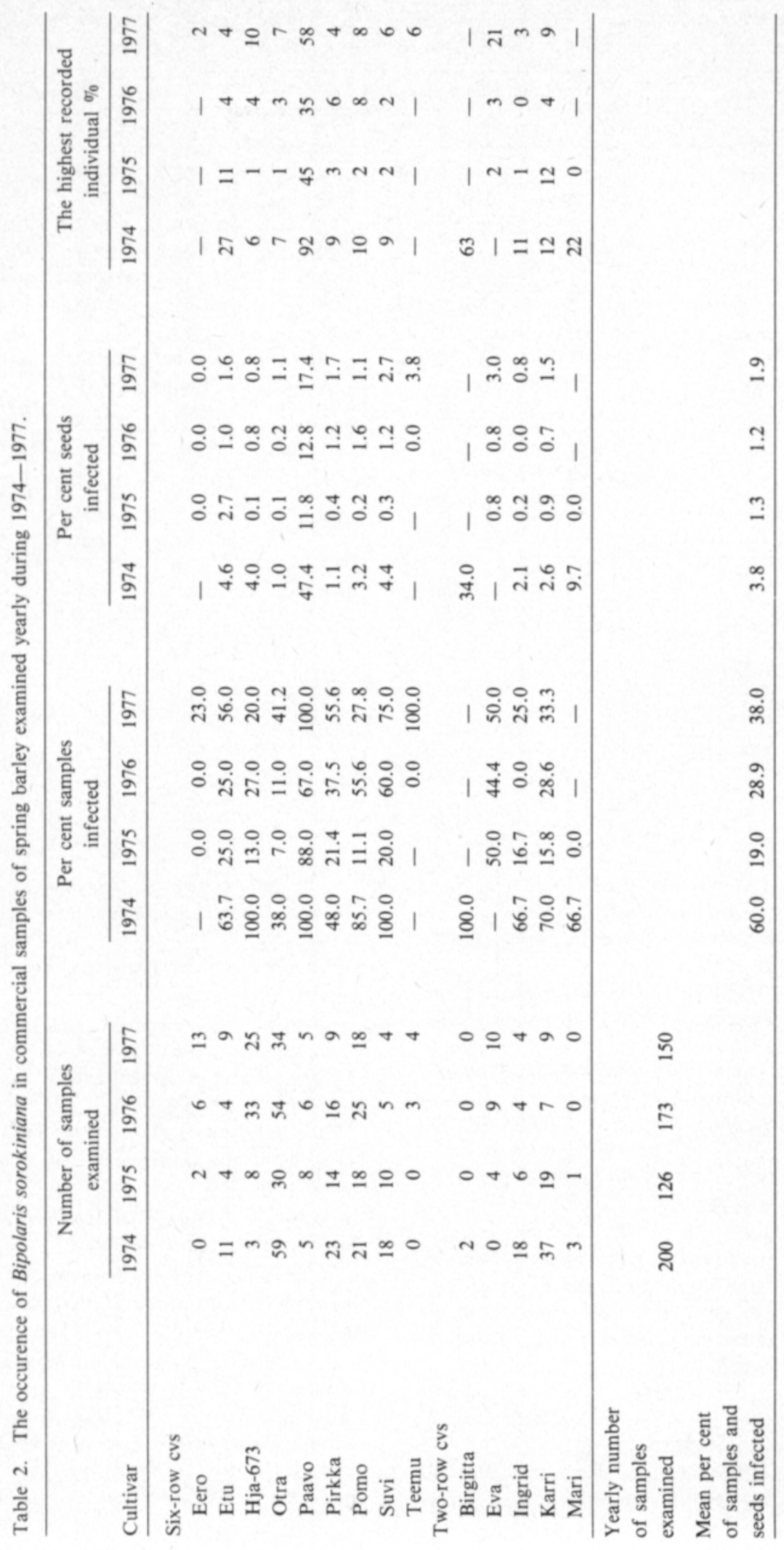


Table 3. The regional occurence of Bipolaris sorokiniana in Finland during the growing seasons 1974-1977 as determined by a survey of commercial samples of spring barley.

\begin{tabular}{|c|c|c|c|c|c|c|c|c|}
\hline \multirow[b]{2}{*}{ County' } & \multicolumn{4}{|c|}{ Number of samples examined } & \multicolumn{4}{|c|}{ Per cent samples infected } \\
\hline & 1974 & 1975 & 1976 & 1977 & 1974 & 1975 & 1976 & 1977 \\
\hline 1 Turku and Pori & 57 & 43 & 72 & 63 & 62.6 & 20.9 & 26.4 & 23.8 \\
\hline 2 Uusimaa & 31 & 24 & 31 & 15 & 62.5 & 16.7 & 45.2 & 46.7 \\
\hline $3 \mathrm{Kymi}$ & 27 & 11 & 24 & 13 & 66.7 & 18.2 & 29.2 & 84.6 \\
\hline 4 Häme & 30 & 15 & 6 & 20 & 65.9 & 13.3 & 16.6 & 35.0 \\
\hline 5 Mikkeli & 11 & 1 & 1 & 2 & 71.4 & $(100.0)$ & $(100.0)$ & $(50.0)$ \\
\hline 6 Vaasa & 22 & 20 & 27 & 26 & 43.5 & 10.0 & 11.1 & 34.6 \\
\hline 7 Central Finland & 6 & 0 & 5 & 8 & 83.3 & - & 60.0 & 62.5 \\
\hline 8 Kuopio & 13 & 5 & 5 & 3 & 76.9 & 20.0 & 40.0 & 66.7 \\
\hline 9 Northern Karelia & 2 & 0 & 0 & 0 & $(0.0)$ & - & - & - \\
\hline 10 Oulu & 1 & 7 & 2 & 0 & $(100.0)$ & 42.8 & $(50.0)$ & - \\
\hline $\begin{array}{l}\text { Total number of } \\
\text { samples examined }\end{array}$ & 200 & 126 & 173 & 150 & & & & \\
\hline $\begin{array}{l}\text { Mean per cent samples } \\
\text { infected }\end{array}$ & & & & & 63.0 & 19.0 & 28.9 & 38.0 \\
\hline
\end{tabular}

1 See fig. 3.

\section{References}

Anderson, W.H. \& BanttaRi, E.E. 1976. The effect of Bipolaris sorokiniana on yield, kernel weight and kernel discoloration in six-row spring barleys. Pl. Dis. Reptr, 60: 754-758.

ANON. 1972-1979. Kuukausikatsauksia Suomen sääoloihin. Touko-elokuu 1972-1979. Ilmatieteen laitos.

Couture, L. \& Sutron, J.C. 1978. Relation of weather variables and host factors to incidence of airborne spores of Bipolaris sorokiniana. Can. J. Bot. 56: $2162-2170$.

Hewett, P.D. 1975. A health survey of seed barley. Pl. Path. 24: 229-232.

Jørgensen, J. 1969. Species of Fusarium and Helminthosporium on seed of barley grown in Denmark during 1965-1967. Acta Agric. Scand. 19: 92-98.

-, 1974. Occurence and importance of seed borne inoculum of Cochliobolus sativus on barley in Denmark. Acta Agric. Scand. 24: 49-54.

Kietreiber, M. 1973. TătBer 1972. Geshundheitszustand der Saatgutproben. Jb. 1972 Bundesanst. PflBau. Samenpruf. Wien, 59-73.

—, 1974. TătBer 1973. Geshundheitszustand der Saatgutproben. Jb. 1973 Bundesanst. PflBau. Samenpruf. Wien, $65-78$.
KURPPA, A. 1975. Ohran tyvi- ja lehtilaikku - yleistyvă piilevă kasvitauti. Käytănnön Maamies 1975, 7: 20-21.

,- 1982. Sienituhoja siemenviljassa. Pellervo 1982, 8: 30-31.

Mä́elĀ, K. 1971. Some graminicolous species of $\mathrm{Hel}$ minthosporium in Finland. Karstenia 12: 5-35.

- , 1972. Leaf spot fungi on barley in Finland. Acta Agr. Fenn. 124: 1-23.

-, 1975. Occurence of Helminthosporium species on cereals in Finland in 1971-1973. J. Sci. Agric. Soc. Finl. 47: 181-217.

SPraque, R. 1950. Diseases of cereals and grasses in North America. 538 p. New York.

TemPE, J.de. 1964. Helminthosporium spp. in seeds of wheat, barley, oats and rye. Proc. Int. Seed Test. Assoc. 29: 117-140.

Whittle, A.M. 1977. Cochliobolus sativus on barley in Scotland. Pl. Path. 26: 67-74.

-, \& Richardson, M.J. 1978. Yield losses caused by Cochliobolus sativus on Clermont barley. Phytopath. Z. 91 : $238-256$.

Ms received June 29, 1984 


\title{
SELOSTUS
}

\section{Bipolaris sorokiniana-sienen esiintyminen ohran siementavarassa Suomessa}

\author{
Aarne Kurppa
}

Helsingin yliopiston kasvipatologian laitos, 00710 Helsinki 71

Bipolaris sorokiniana (syn. Helminthosporium sativum, koteloaste Cochliobolus sativus) todettiin yleiseksi ja potentiaalisesti haitalliseksi sieneksi ohran siementavarassa vuosina 1972-1979 Helsingin yliopiston kasvipatologian laitoksella suoritetuissa tutkimuksissa. Vuosina 1974-1977 tutkittiin 649 siementavaraksi tarkoitettua ohraerää, joista sienen tartuttamiksi todettiin aikajärjestyksessä 60, 19, 29 ja $38 \%$. Infektoituneita jyviä oli vastaavasti keskimäărin $3.8,1.3,1.2$ ja $1.9 \%$ tutkituista. Lajikkeiden vălillă oli selviă alttiuseroja, Paavo oli infektoitunein kaikkina vuosina ja yleisesti viljelty Otra tervein. Selviä eroja kaksi- ja monitahoisten lajikkeiden alttiudessa ei todettu. Sientă esiintyi maan länsiosissa jonkinverran văhemmän kuin muualla.

B. sorokiniana esiintyi useimmiten rihmastona siemenkuoressa, mutta monissa tapauksissa se oli infektoinut myös alkion ja sen läheiset solukerrokset, mikä ai- heutti siemenen itămättömyyden tai oraan sairastumisen heti itämisen jälkeen.

Vuosina 1972 - 1979 tutkittujen kenttäkokeiden satonăytteiden tulokset tukivat otannalla saatuja tuloksia. Koska sieni infektoi jyvăsadon sekundäärisesti tuulen mukana leviävien kuromien vălityksellä, sen runsaus siemenissä kytkeytyi erityisesti heinä- ja elokuun sademääriin, suhteelliseen ilmankosteuteen ja myös kasvustojen lakoisuuteen. Erityisen kuivissa olosuhteissa sieni ei infektoinut kypsyvää jyväsatoa lainkaan.

Sienen todellinen merkitys siemenlevintäisenă taudinaiheuttajana riippuu jyvien infektoituneisuusasteesta; onko sieni vain siemenkuoressa, vaiko myös alkiossa. Pelkän siemenkuoritartunnan saanut kylvösiemen voidaan puhdistaa tehokkaasti taudinaiheuttajasta elohopeapitoisella valmisteella peittaamalla. Toimenpide rajoittaa osaltaan myös sienen lisäăntyväă haitallisuutta maalevintăisenä taudinaiheuttajana. 